\title{
Absorption Coefficient of Particulate Matter in Lake Haruna
}

\author{
Akira Sugawa and Kumiko Yajima
}

\begin{abstract}
The absorption coefficient of particulate matter at wave length $\lambda, a_{p}(\lambda)$, is expressed by the sum of the absorption coefficients of detritus $a_{d}(\lambda)$ and phytoplankton $a_{p l}(\lambda)$, and $a_{p l}(\lambda)$ is given by the product of the specific absorption coefficient of chlorophyll- $a a_{p h}(\lambda)$ and chlorophyll- $a$ concentration at depth $z, C(z)$.

The value of $a_{p h}(\lambda)$ in the region $400 \sim 700 \mathrm{~nm}$ is maximum at $\lambda=440 \mathrm{~nm}$, so in Lake Haruna $a_{p}(440)$ and $C(z)$ were measured, and $a_{d}(440)$ and $a_{p l}(440)$ were obtained. The value of $a_{p}(440)$ at $z=12 \mathrm{~m}$ except that on 16 November was much larger than at $z=0,4$, and $8 \mathrm{~m}$. This may be caused by turbulence which may be effected by bottom current.

When the lake water is divided into some layers, let $a_{p}(440)_{i}$ and $\Delta z_{i}$ be the value of $a_{p}(440)$ and thickness of the $i$-th layer and let $z_{n}$ be the depth of the lower plane of the $n$-th layer. For the same solar altitude, absorptance by particulate matter in the lake water between $z=0$ and $z_{n}, A_{p}(440)_{z n}$, increases as the value of $\sum_{i=1}^{n} a_{p}(440)_{i} \Delta z_{i}$ increases. Accordingly, the value of $\sum_{i=1}^{n} a_{p}(440){ }_{i} \Delta z_{i}$ in each month was calculated and compared instead of the value of $A_{p}(440)_{z n}$. Similarly, values of $\sum_{i=1}^{n} a_{d}(440)_{i} \Delta z_{i}$ and $\sum_{i=1}^{n} a_{p l}(440){ }_{i} \Delta z_{i}$ were calculated and compared. $a_{d}(440)_{i}$ and $a_{p l}(440)_{i}$ are the values of $a_{d}(440)$ and $a_{p l}(440)$ of the $i$-th layer.
\end{abstract}

Key words : chlorophyll- $a$ concentration, specific absorption coefficient of chlorophyll- $a$, bottom current, water temperature.

\section{Introduction}

The absorption coefficient of particulate matter in sea water was measured by LORENZEN (1972), Jerlov (1976), Morel and Prieur (1977), Prieur and Sathyendranath (1981), and Maske and HAARDT (1987). That in lake water was measured by KIRK (1980), WeIDEMANN and Bannister (1986), and Sugawa (1989), while those in sea and lake waters were measured by KISHINo et al. (1984).

When the absorption coefficient of particulate matter and the chlorophyll- $a$ concentration are measured, absorption coefficients of detritus and phytoplankton are obtained. Prieur and Sathyendranath (1981), and Sathyendranath et al. (1987) showed that the specific absorption coefficient of chlorophyll- $a$ in the region $400 \sim 700 \mathrm{~nm}$ is maximum at 440 $\mathrm{nm}$, so absorption coefficients of particulate matter, detritus, and phytoplankton at $440 \mathrm{~nm}$ in Lake Haruna were obtained.

\section{Specific absorption coefficient of chloro- phyll-a}

Absorption coefficient of particulate matter at wave length $\lambda, a_{p}(\lambda)$, is given by

$$
\begin{gathered}
a_{p}(\lambda)=a_{d}(\lambda)+a_{p l}(\lambda) \\
a_{p l}(\lambda)=a_{p h}(\lambda) C(z)
\end{gathered}
$$

where $a_{d}(\lambda)$ and $a_{p l}(\lambda)$ are absorption coefficients of detritus aind phytoplankton, respectively, and $a_{p h}(\lambda)$ and $C(z)$ are the specific absorption coefficient of chlorophyll- $a$ and chlorophyll- $a$ concentration at depth $z$, respectively. Eq. (2-1) becomes 


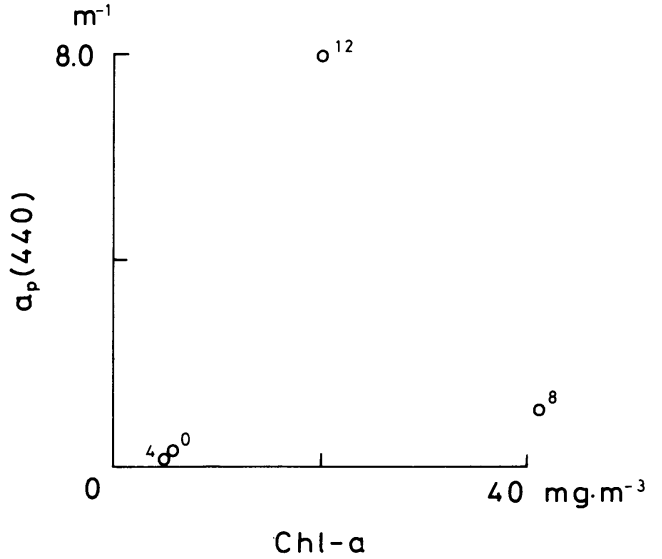

Fig. 1. Relation between $a_{p}(440)$ and $C(z)$ on 7 July.

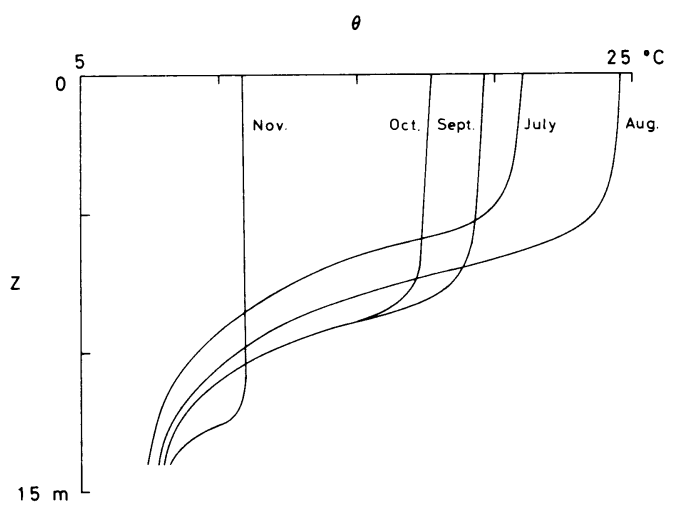

Fig. 2. Vertical distribution of water temperature in Lake Haruna in 1987.

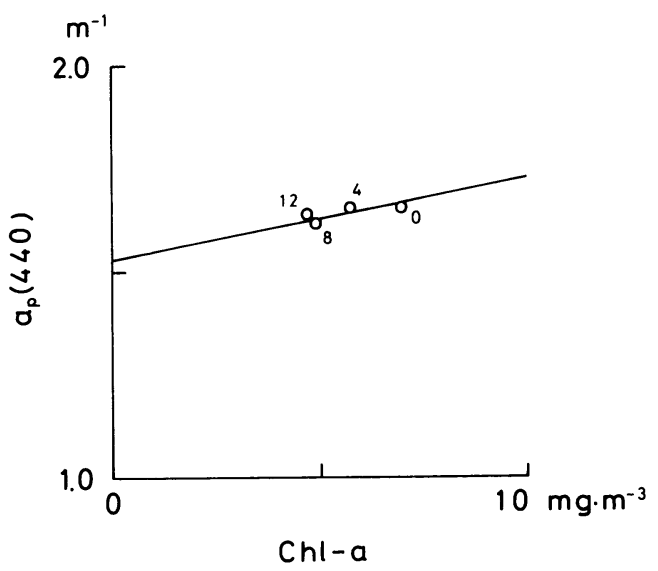

Fig. 3. Relation between $a_{p}(440)$ and $C(z)$ on 16 November.

$$
a_{p}(\lambda)=a_{d}(\lambda)+a_{p h}(\lambda) C(z)
$$

Then $a_{p}(440)$ and $a_{p l}(440)$ become

$$
\begin{gathered}
a_{p}(440)=a_{d}(440)+a_{p h}(440) C(z) \\
a_{p l}(440)=a_{p h}(440) C(z)
\end{gathered}
$$

If $a_{d}(440)$ is constant, the relation between $a_{p}$ (440) and $C(z)$ is linear.

In Lake Haruna water samples were collected from $z=0,4,8,12 \mathrm{~m}$, and $a_{p}(440)$ and $C$ $(z)$ were measured by the methods described by Sugawa (1989) and Sajo (1975). The dates of collection are presented in Table 1. The depth of the lake bottom varied from 14.3 to $15.0 \mathrm{~m}$ during the period from July to November. Figure 1 shows the relation between $a_{p}(440)$ and $C(z)$ on $7 \mathrm{July}$, and the numerals on the open circles present the depths of collection. The open circles are not on a straight line. This indicates that the value of $a_{d}(440)$ at each depth is not costant. In Lake Haruna water temperature was measured when the water samples were collected. The vertical distribution of the water temperature is shown in Figure 2. In the case on 7 July, the thermocline was clearly recognized as shown in Figure 2. Then the lake water may not be apt to circulate, and detritus concentration at each depth may not become constant.

Figure 3 shows the relation between $a_{p}(440)$ and $C(z)$ on 16 November, and the numerals on the open circles indicate the depths of collection. The open circles are approximately on a straight line, showing the constant value of $a_{d}$ (440) at each depth. In this case, from (2-4) the value of $a_{p}(440)$ at $C(z)=0$ is equal to the value of $a_{d}(440)$ and the value is $1.52 \mathrm{~m}^{-1}$. In the case on 16 November, the water temperature from $z=0$ to $12 \mathrm{~m}$ was constant. Then the lake water may be apt to circulate, and detritus concentration at each depth may become constant.

From the slope of the straight line in Figure 3 , the value of $a_{p h}(440)$ is obtained as $0.021 \mathrm{~m}^{-1}$ (mg Chl- $\left.a \cdot \mathrm{m}^{-3}\right)^{-1}$. LORENZEN ( 1972 ), MOREL and PRIEUR (1977) obtained the average value of $a_{p h}(\lambda)$ in the region $400 \sim 700 \mathrm{~nm}$ as 0.0138 and 
$0.0142 \mathrm{~m}^{-1}\left(\mathrm{mg} \mathrm{Chl}-a \cdot \mathrm{m}^{-3}\right)^{-1}$. BAnnister (1974) proposed the average value as $0.016 \mathrm{~m}^{-1}(\mathrm{mg}$ Chl $\left.-a \cdot \mathrm{m}^{-3}\right)^{-1}$. The value of $a_{p h}(440)$ in Lake Haruna is larger than the above average values.

\section{Absorption coefficients of particulate matter, detritus, and phytoplankton}

When the values of $a_{p}(440)$ and $C(z)$ are measured, the value of $a_{p l}(440)$ is obtained from Eq. $(2-5)$, in which the value of $a_{p h}(440)$ is 0.021 $\mathrm{m}^{-1}\left(\mathrm{mg} \mathrm{Chl}-a \cdot \mathrm{m}^{-3}\right)^{-1}$, and the value of $a_{d}(440)$ is obtained from Eq. (2-4). The values of $C$ $(z), a_{p}(440), a_{d}(440)$, and $a_{p l}(440)$ in Lake Haruna are given in Table 1.

The value of $C(z)$ at $z=12 \mathrm{~m}$ except that on 16 November ranged from 20.5 to $107.7 \mathrm{mg} \cdot \mathrm{m}^{-3}$ and was much larger than at $z=0,4,8 \mathrm{~m}$, but that at $z=8 \mathrm{~m}$ on $7 \mathrm{July}$ was $41.0 \mathrm{mg} \cdot \mathrm{m}^{-3}$ and larger than at $z=12 \mathrm{~m}$. The value of $C(z)$ at $z=8 \mathrm{~m}$ except that on 16 November ranged from 3.7 to $41.0 \mathrm{mg} \cdot \mathrm{m}^{-3}$ and was larger than at $z=0$ and $4 \mathrm{~m}$. That at $z=12 \mathrm{~m}$ on 16 November was $4.7 \mathrm{mg} \cdot \mathrm{m}^{-3}$ and slightly smaller than at $z=0,4,8 \mathrm{~m}$.
The value of $a_{p l}(440)$ is proportional to the value of $C(z)$, so the vertical distribution of $a_{p l}$ (440) is similar to that of $C(z)$. The value of $a_{p l}(440)$ at $z=12 \mathrm{~m}$ except that on 16 November ranged from 0.43 to $2.26 \mathrm{~m}^{-1}$ and was also much larger than at $z=0,4,8 \mathrm{~m}$, but that at $z=8 \mathrm{~m}$ on 7 July was $0.86 \mathrm{~m}^{-1}$ and larger than at $z=12 \mathrm{~m}$. The value of $a_{p l}(440)$ at $z=8 \mathrm{~m}$ except for 16 November ranged from 0.08 to $0.86 \mathrm{~m}^{-1}$ and was larger than at $z=0$ and $4 \mathrm{~m}$. That at $z=12 \mathrm{~m}$ on 16 November was $0.10 \mathrm{~m}^{-1}$ and slightly smaller than at $z=0,4,8 \mathrm{~m}$.

The value of $a_{d}(440)$ at $z=12 \mathrm{~m}$ except for 16 November ranged from 1.51 to $7.52 \mathrm{~m}^{-1}$ and was much larger than at $z=0,4,8 \mathrm{~m}$, and that at $z=$ $8 \mathrm{~m}$ ranged from 0.25 to $0.97 \mathrm{~m}^{-1}$ and was larger than at $z=0$ and $4 \mathrm{~m}$. The values of $a_{d}(440)$ at $z=0$ and $4 \mathrm{~m}$ except those on 7 July and 16 November ranged from 0.42 to $0.69 \mathrm{~m}^{-1}$, but those at $z=0$ and $4 \mathrm{~m}$ in each month were nearly equal. The value of $a_{d}(440)$ at each depth on 16 November ranged from 1.50 to 1.54 $\mathrm{m}^{-1}$, and was slightly different from $a_{d}(440)=$ $1.52 \mathrm{~m}^{-1}$ obtained in Figure 3. This is caused

Table 1. Values of $C(z), a_{p}(440), a_{d}(440), a_{p l}(440)$, and $a_{d}(440) / a_{p l}(440)$.

\begin{tabular}{|c|c|c|c|c|c|c|c|}
\hline & $\begin{array}{l}\text { Date } \\
(1987)\end{array}$ & $\begin{array}{l}\text { Depth } \\
(\mathrm{m})\end{array}$ & $\begin{array}{c}C(z) \\
\left(\mathrm{mg} \cdot \mathrm{m}^{-3}\right)\end{array}$ & $\begin{array}{c}a_{p}(440) \\
\left(\mathrm{m}^{-1}\right)\end{array}$ & $\begin{array}{c}a_{d}(440) \\
\left(\mathrm{m}^{-1}\right)\end{array}$ & $\begin{array}{c}a_{p l}(440) \\
\left(\mathrm{m}^{-1}\right)\end{array}$ & $a_{d}(440) / a_{p l}(440)$ \\
\hline \multirow{4}{*}{7} & \multirow{4}{*}{ July } & 0 & 5.6 & 0.32 & 0.20 & 0.12 & 1.67 \\
\hline & & 4 & 5.2 & 0.15 & 0.04 & 0.11 & 0.36 \\
\hline & & 8 & 41.0 & 1.11 & 0.25 & 0.86 & 0.29 \\
\hline & & 12 & 20.5 & 7.95 & 7.52 & 0.43 & 17.5 \\
\hline \multirow{4}{*}{20} & \multirow{4}{*}{ August } & 0 & 3.7 & 0.77 & 0.69 & 0.08 & 8.63 \\
\hline & & 4 & 6.0 & 0.77 & 0.64 & 0.13 & 4.92 \\
\hline & & 8 & 9.1 & 1.16 & 0.97 & 0.19 & 5.11 \\
\hline & & 12 & 107.7 & 3.77 & 1.51 & 2.26 & 0.67 \\
\hline \multirow{4}{*}{24} & \multirow{4}{*}{ September } & 0 & 5.7 & 0.54 & 0.42 & 0.12 & 3.50 \\
\hline & & 4 & 6.7 & 0.57 & 0.43 & 0.14 & 3.07 \\
\hline & & 8 & 10.5 & 1.03 & 0.81 & 0.22 & 3.68 \\
\hline & & 12 & 94.9 & 4.29 & 2.30 & 1.99 & 1.16 \\
\hline \multirow{4}{*}{6} & \multirow{4}{*}{ October } & 0 & 2.4 & 0.68 & 0.63 & 0.05 & 12.6 \\
\hline & & 4 & 2.1 & 0.64 & 0.60 & 0.04 & 15.0 \\
\hline & & 8 & 3.7 & 0.94 & 0.86 & 0.08 & 10.8 \\
\hline & & 12 & 63.5 & 4.01 & 2.68 & 1.33 & 2.02 \\
\hline \multirow{4}{*}{16} & \multirow{4}{*}{ November } & 0 & 7.0 & 1.65 & 1.50 & 0.15 & 10.0 \\
\hline & & 4 & 5.7 & 1.65 & 1.53 & 0.12 & 12.8 \\
\hline & & 8 & 4.9 & 1.62 & 1.52 & 0.10 & 15.2 \\
\hline & & 12 & 4.7 & 1.64 & 1.54 & 0.10 & 15.4 \\
\hline
\end{tabular}



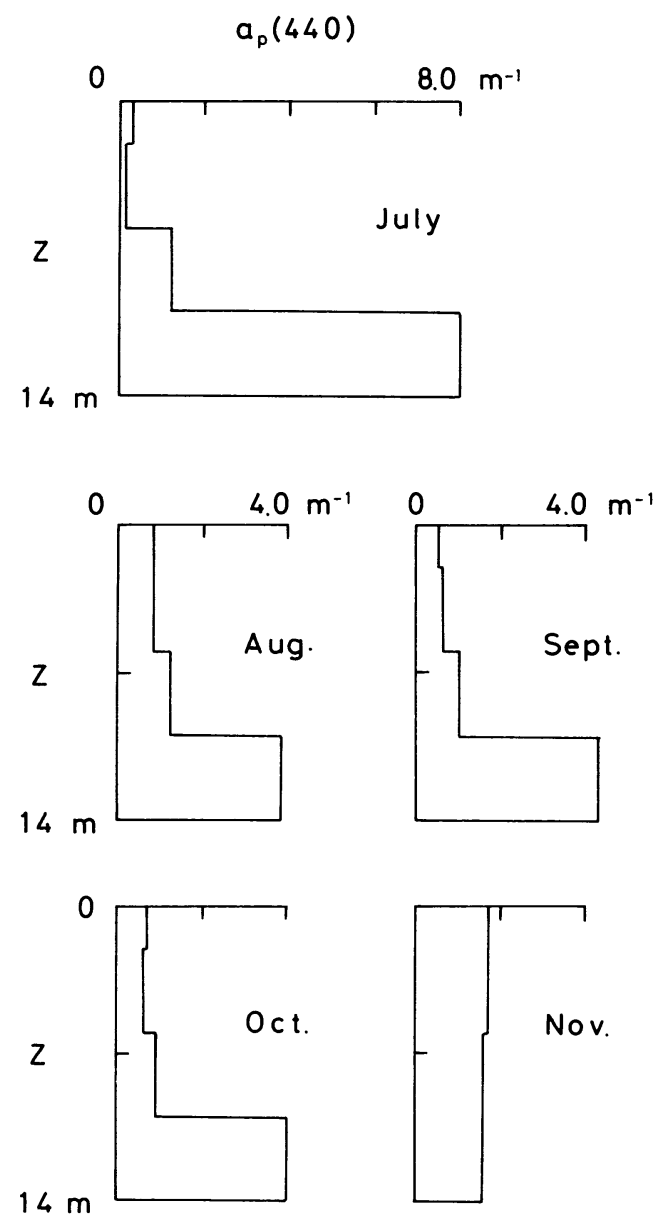

Fig. 4. Vertical distribution of $a_{p}(440)$.

by deviation of the open circles from the straight line in Figure 3, but the mean value becomes $1.52 \mathrm{~m}^{-1}$.

When the value of $a_{d}(440)$ or $a_{p l}(440)$ is large, from Eq. (2-1) the value of $a_{p}(440)$ becomes large. The value of $a_{p}(440)$ at $z=12$ $m$ except for 16 November ranged from 3.77 to $7.95 \mathrm{~m}^{-1}$ and was much larger than at $z=0,4,8$ $\mathrm{m}$, while that at $z=8 \mathrm{~m}$ ranged from 0.94 to 1.16 $\mathrm{m}^{-1}$ and was larger than at $z=0$ and $4 \mathrm{~m}$. The values of $a_{p}(440)$ at $z=0$ and $4 \mathrm{~m}$ except those on 7 July and 16 November ranged from 0.54 to $0.77 \mathrm{~m}^{-1}$, but those at $z=0$ and $4 \mathrm{~m}$ in each month were nearly equal. That at each depth on 16 November ranged from 1.62 to $1.65 \mathrm{~m}^{-1}$.

\section{Discussion}

JERLOV (1976) found a bottom scattering layer
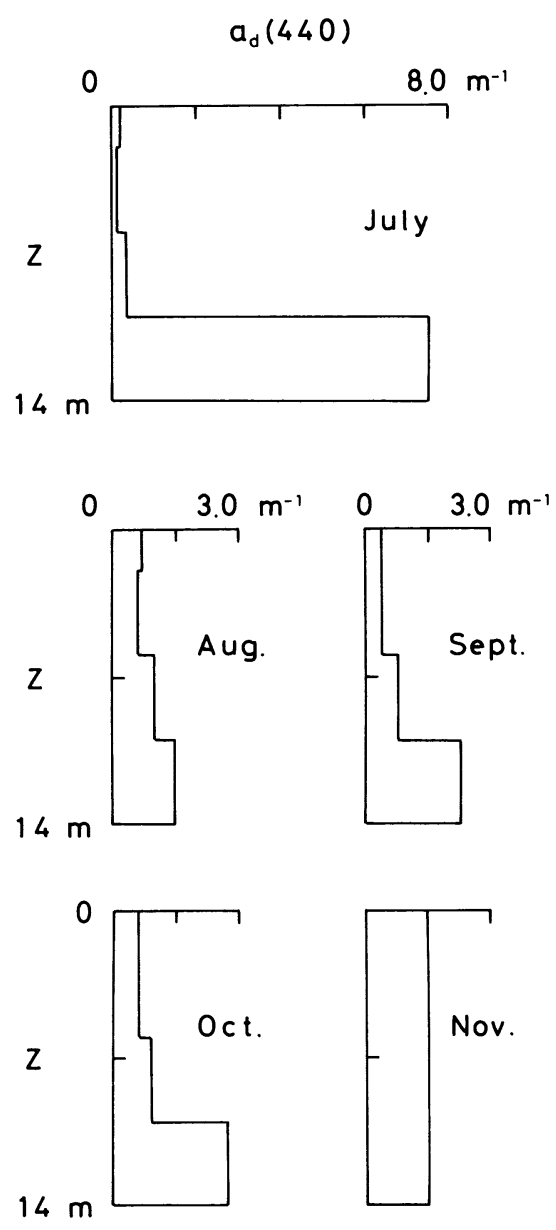

Fig. 5. Vertical distribution of $a_{d}(440)$.

in which the scattering coefficient was very large, and estimated that the turbulence effected by bottom current leads to an increase of scattering. When part of the sedimented particulate matter is elevated by the turbulence and the particulate matter concentration increases, the value of $a_{p}(440)$ near the lake bottom may become large.

In Lake Haruna, during the period from July to October, the thermocline was clearly recognized as shown in Figure 2, so the lake water may not be apt to circulate and the particulate matter near the lake bottom may not ascend to the shallow depth. Then the value of $a_{p}(440)$ at $z=12 \mathrm{~m}$ became much larger than at $z=0,4$, and $8 \mathrm{~m}$. Since the water temperature between $z=0$ and $4 \mathrm{~m}$ was nearly constant, the lake water between $z=0$ and $4 \mathrm{~m}$ may be apt to 

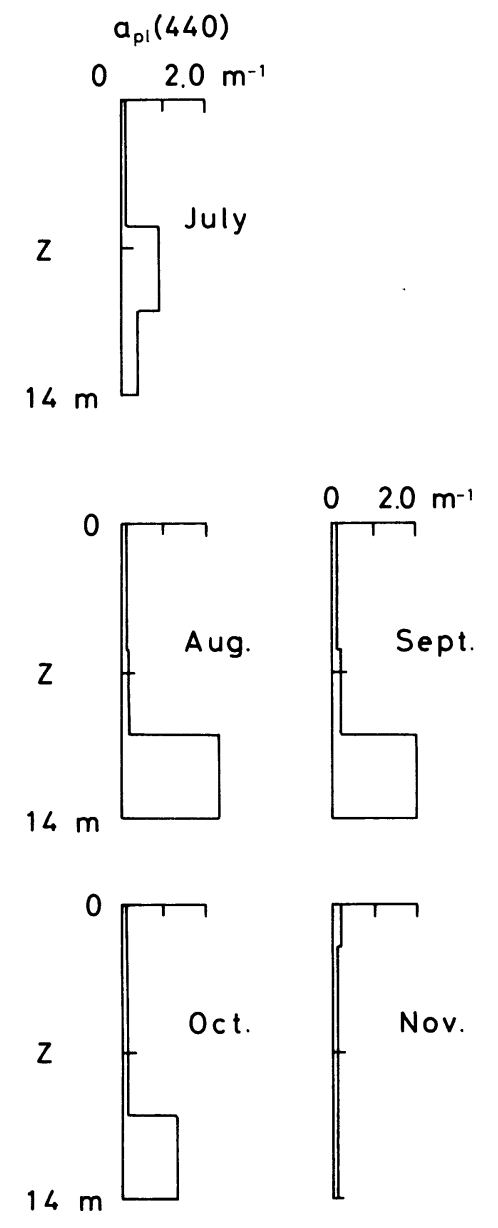

Fig. 6. Vertical distribution of $a_{p l}(440)$.

circulate, and the values of $a_{p}(440)$ at $z=0$ and $4 \mathrm{~m}$ became nearly equal except for $7 \mathrm{July}$. On 16 November, a weak thermocline was recognized near the lake bottom and the water temperature from $z=0$ to $12 \mathrm{~m}$ was constant, so the lake water may be apt to circulate and the particulate matter near the lake bottom may ascend to the lake surface. Then the value of $a_{p}(440)$ at each depth became approximately equal.

The value of $a_{d}(440)$ was usually larger than the value of $a_{p l}(440)$ at the same depth. The ratio of $a_{d}(440)$ to $a_{p l}(440)$ is given in Table 1 and is often larger than 10. Then the absorption by the particulate matter depends on the detritus.

If a water layer is homogeneous, absorptance by particulate matter at $\lambda=440 \mathrm{~nm}, A_{p}(440)$, is given by

$$
\begin{gathered}
\ln \left\{1-A_{p}(440)\right\}=-a_{p}(440) \Delta z \sec j \\
A_{p}(440)=F_{p}(440) / F_{o}(440)
\end{gathered}
$$

where $j$ is the angle of refraction of direct solar radiation at $\lambda=440 \mathrm{~nm}$ at the lake surface, $\Delta z$ is the thickness of the layer, $F_{p}(440)$ is radiant flux at $\lambda=440 \mathrm{~nm}$ lost by the absorption of particulate matter, and $F_{o}(440)$ is incident radiant flux at $\lambda=440 \mathrm{~nm}$ into the layer.

If the lake water from $z=0$ to $14 \mathrm{~m}$ is divided into the layers $z=0$ to $2 \mathrm{~m}, 2$ to $6 \mathrm{~m}, 6$ to $10 \mathrm{~m}$, and 10 to $14 \mathrm{~m}$, and the values of $a_{p}(440), a_{d}$ (440), $a_{p l}(440)$ of the layers are assumed to be equal to those at $z=0,4,8$, and $12 \mathrm{~m}$, the vertical distributions of $a_{p}(440), a_{d}(440)$, and $a_{p l}(440)$ are shown as in Figures 4,5 , and 6 . Let $\Delta z_{i}$ be the thickness of the $i$-th layer and let $a_{p}(440)_{i}, a_{d}(440)_{i}, a_{p l}(440)_{i}$ be the values of $a_{p}$ (440), $a_{d}(440), a_{p l}(440)$ of the $i$-th layer. Let $z_{n}$ be the depth of the lower plane of the $n$-th layer and let $A_{p}(440)_{z n}, A_{d}(440)_{z n}$, and $A_{p l}$ $(440)_{z n}$ be the absorptances by particulate matter, detritus, and phytoplankton in the lake water between $z=0$ and $z_{n}$. From Eq. (4-1) $A_{p}$ $(440)_{z n}$ is given by

$$
\ln \left\{1-A_{p}(440)_{z n}\right\}=-\sum_{i=1}^{n} a_{p}(440)_{i} \Delta z_{i} \sec j
$$

similarly, $A_{d}(440)_{z n}$ and $A_{p l}(440)_{z n}$ are given by

$$
\begin{aligned}
& \ln \left\{1-A_{d}(440)_{z n}\right\}=-\sum_{i=1}^{n} a_{d}(440)_{i} \Delta z_{i} \sec j \\
& \ln \left\{1-\mathrm{A}_{p l}(440)_{z n}\right\}=-\sum_{i=1}^{n} a_{p l}(440)_{i} \Delta z_{i} \sec j
\end{aligned}
$$

For the same angle of $j$, from Eq. (4-3) the value of $A_{p}(440)_{z n}$ increases as the value of $\sum_{i=1}^{n}$ $a_{p}(440)_{i} \Delta z_{i}$ increases. Similarly, from Eqs. (4-4) and (4-5) the values of $A_{d}(440)_{z n}$ and $A_{p l}$ $(440)_{z n}$ increase as the values of $\sum_{i=1}^{n} a_{d}(440)_{i} \Delta z_{i}$ and $\sum_{i=1}^{n} a_{p l}(440)_{i} \Delta z_{i}$ increase. From Figures 4 , 5 , and 6 , the values of $\sum_{i=1}^{n} a_{p}(440)_{i} \Delta z_{i}, \sum_{i=1}^{n} a_{d}$ (440) ${ }_{i} \Delta z_{i}$, and $\sum_{i=1}^{n} a_{p l}(440)_{i} \Delta z_{i}$ are calculated and given in Table 2. These values were compared instead of the values of $A_{p}(440)_{z n}, A_{d}$ $(440)_{z n}$, and $A_{p l}(440)_{z n}$.

The values of $\sum_{i=1}^{n} a_{p}(440)_{i} \Delta z_{i}$ for $z_{n}=2,6$, and 
Table 2. Values of $\sum_{i=1}^{n} a_{p}(440)_{i} \Delta z_{i}, \sum_{i=1}^{n} a_{d}(440){ }_{i} \Delta z_{i}$, and $\sum_{i=1}^{n} a_{p l}(440)_{i} \Delta z_{i}$.

\begin{tabular}{|c|c|c|c|c|c|}
\hline & $\begin{array}{l}\text { Date } \\
(1987)\end{array}$ & $\begin{array}{c}z_{n} \\
(\mathrm{~m})\end{array}$ & $\sum_{i=1}^{n} a_{p}(440)_{i} \Delta z_{i}$ & $\sum_{i=1}^{n} a_{d}(440)_{i} \Delta z_{i}$ & $\sum_{i=1}^{n} a_{p l}(440)_{i} \Delta z_{i}$ \\
\hline \multirow{4}{*}{7} & \multirow{4}{*}{ July } & 2 & 0.64 & 0.40 & 0.24 \\
\hline & & 6 & 1.24 & 0.56 & 0.68 \\
\hline & & 10 & 5.68 & 1.56 & 4.12 \\
\hline & & 14 & 37.5 & 31.6 & 5.84 \\
\hline \multirow{4}{*}{20} & \multirow{4}{*}{ August } & 2 & 1.54 & 1.38 & 0.16 \\
\hline & & 6 & 4.62 & 3.94 & 0.68 \\
\hline & & 10 & 9.26 & 7.82 & 1.44 \\
\hline & & 14 & 24.3 & 13.9 & 10.5 \\
\hline \multirow{4}{*}{24} & \multirow{4}{*}{ September } & 2 & 1.08 & 0.82 & 0.24 \\
\hline & & 6 & 3.36 & 2.56 & 0.80 \\
\hline & & 10 & 7.48 & 5.80 & 1.68 \\
\hline & & 14 & 24.6 & 15.0 & 9.64 \\
\hline \multirow{4}{*}{6} & \multirow{4}{*}{ October } & 2 & 1.36 & 1.26 & 0.10 \\
\hline & & 6 & 3.92 & 3.66 & 0.26 \\
\hline & & 10 & 7.68 & 7.10 & 0.58 \\
\hline & & 14 & 23.7 & 17.8 & 5.90 \\
\hline \multirow{4}{*}{16} & \multirow{4}{*}{ November } & 2 & 3.30 & 3.00 & 0.30 \\
\hline & & 6 & 9.90 & 9.12 & 0.78 \\
\hline & & 10 & 16.4 & 15.2 & 1.18 \\
\hline & & 14 & 22.9 & 21.4 & 1.58 \\
\hline
\end{tabular}

$10 \mathrm{~m}$ on 16 November were $3.30,9.90,16.4$ and larger than in other months, while that for $z_{n}=$ $14 \mathrm{~m}$ was 22.9 and smaller than in other months, because the value of $a_{p}(440)$ between $z=10$ and $14 \mathrm{~m}$ was smaller than in other months. The values of $\sum_{i=1}^{n} a_{p}(440)_{i} \Delta z_{i}$ for $z_{n}=2,6$, and $10 \mathrm{~m}$ on 7 July were $0.64,1.24,5.68$ and smaller than in other months, while that at $z_{n}=14 \mathrm{~m}$ was 37.5 and larger than in other months, because the value of $a_{p}(440)$ between $z=10$ and $14 \mathrm{~m}$ was much larger than in other months.

The values of $\sum_{i=1}^{n} a_{d}(440)_{i} \Delta z_{i}$ for $z_{n}=2,6$, and $10 \mathrm{~m}$ on 16 November were $3.00,9.12,15.2$ and larger than in other months, but that for $z_{n}=14$ $\mathrm{m}$ was 21.4 and smaller than on $7 \mathrm{July}$, because the value of $a_{d}(440)$ between $z=10$ and $14 \mathrm{~m}$ was much smaller than on 7 July. The values of $\sum_{i=1}^{n} a_{d}(440)_{i} \Delta z_{i}$ for $z_{n}=2,6$, and $10 \mathrm{~m}$ on 7 July were $0.40,0.56,1.56$ and smaller than in other months, while that at $z_{n}=14 \mathrm{~m}$ was 31.6 and larger than in other months, because the value of $a_{d}$ (440) between $z=10$ and $14 \mathrm{~m}$ was much larger than in other months.
The value of $\sum_{i=1}^{n} a_{p l}(440)_{i} \Delta z_{i}$ for $z_{n}=10 \mathrm{~m}$ on 7 July was 4.12 and larger than in other months, because the value of $a_{p l}(440)$ between $z=6$ and $10 \mathrm{~m}$ was much larger than in other months. The values of $\sum_{i=1}^{n} a_{p l}(440){ }_{i} \Delta z_{i}$ for $z_{n}=2,6$, and $10 \mathrm{~m}$ on 6 October were $0.10,0.26,0.58$ and smaller than in other months, and that for $z_{n}=$ $14 \mathrm{~m}$ on 16 November was 1.58 and smaller than in other months. This is due to the small values of $a_{p l}(440)$ between $z=0$ and $10 \mathrm{~m}$ on 6 October and between $z=10$ and $14 \mathrm{~m}$ on 16 November.

\section{Acknowledgements}

We wish to express our thanks to Messrs. M. UCHIYAma and Y. NaKajIma of Gunma Institute of Public Health, and Mr. A. TAGuchi of Gunma University for their assistance in the field measurements. 
摘 要

\section{榛名湖内の懸濁物の吸収係数}

湖水中の懸濁物の波長 $\lambda$ の吸収係数 $a_{p}(\lambda)$ は, 植物プランクトン以外の懸濁物の吸収係数 $a_{d}(\lambda)$ と 植物プランクトンの吸収係数 $a_{p l}(\lambda)$ の和で表され る。また $a_{p l}(\lambda)$ はクロロフィル- $a$ の単位濃度当り の吸収係数 $a_{p h}(\lambda)$ と深さ $z$ におる クロロフィル- $a$ の濃度 $C(z)$ の積で表される。 $\lambda=400 \sim 700 \mathrm{~nm}$ の範囲では $a_{p h}(\lambda)$ の値は $\lambda=440$ $\mathrm{nm}$ で最大となるので, 榛名湖において $a_{p}(440)$ と $C(z)$ の值を測定した。そして $a_{d}(440)$ と $a_{p l}(440)$ の值を求めた。11月を除き深さ $12 \mathrm{~m}$ での $a_{p}(440)$ の值は, 深さ $0,4,8 \mathrm{~m}$ での值より大変大きいこ とがわかった。これは湖底流のため湖底近くで乱 流が起こり，そのため湖底に沈殿した眯濁物の一 部が上昇し，懸濁物の濃度が湖底に近いほど大き くなるためと思われる。

湖水中の懸濁物による absorptance を求めるた め, 湖面から深さ $14 \mathrm{~m}$ までの湖水を 4 層に分けた。 第 $n$ 層の下の面の深さを $z_{n}$ とし, 湖面から深さ $z_{n}$ までの湖水中の懸濁物による $\lambda=440 \mathrm{~nm} の$ absorptance を $A_{p}(440)_{z n}$ とする。また第 $i$ 層の $a_{p}(440)$ の値を $a_{p}(440)_{i}$, その厚さを $\Delta z_{i}$ とすると, 等しい 太陽高度に対して, $A_{p}(440)_{z n}$ の值は $\sum_{i=1}^{n} a_{p}(440)_{i}$ $\Delta z_{i}$ の值が大きいほど大きくなる。従って $A_{p}(440)_{z n}$ の値の代わりに $\sum_{i=1}^{n} a_{p}(440)_{i} \Delta z_{i}$ の値を月別に,また $z_{n}$ を変えて計算し，その值を比較した。同様に $a_{d}$ $(440)_{i}, a_{p l}(440)_{i}$ をそれぞれ第 $i$ 層の $a_{d}(440), a_{p l}$ (440)の值とし, $\sum_{i=1}^{n} a_{d}(440)_{i} \Delta z_{i}, \sum_{i=1}^{n} a_{p l}(440)_{i} \Delta z_{i}$ の值を計算し, その値を比較した。

\section{References}

BAnNister, T. T. (1974) : Production equations in terms chlorophyll concentration, quantum yield, and upper limit to production. Limnol. Oceanogr., $19: 1-12$.

Jerlov, N. G. (1976) : Marine optics. Elsevier.

KIRK, J. T. O. (1980) : Spectral absorption properties of natural waters : Contribution of the soluble and particulate fractions to light absorption in some inland waters of south eastern Australia. Aust. J. Mar. Freshwater
Res., $31: 287-296$.

Kishino, M., C. R. Booth and N. OKami (1984) : Underwater radiant energy absorbed by phytoplankton, detritus, dissolved organic matter and pure water. Limnol. Oceanogr., $29: 340^{-}$ 349 .

LoRENzEN, C. J. (1972) : Extinction of light in the ocean by phytoplankton. J. Cons. int. Explor. Mer, $34: 262-267$.

MASKE, H. and H. HAARDT (1987): Quantitative in vivo absorption spectra of phytoplankton : Detrital absorption and comparison with fluorescence excitation spectra. Limnol. Oceanogr., 32 : 620-633.

Morel, A. and L. Prieur (1977) : Analysis of variations in ocean color. Limnol. Oceanogr., 22 : 709-722.

Prieur, L. and S. Sathyendranath (1981): An optical classification of coastal and oceanic waters based on the specific absorption curves of phytoplankton pigments, dissolved organic matter, and other particulate materials. Limnol. Oceanogr., $26: 671-689$.

SAIJo, Y. (1975) : Methods for the quantitative determination of chlorophyll. Jpn. J. Limnol., $36: 103-109$.

Sathyendranath, S., L. Lazzara and L. Prieur (1987) : Variations in the spectral values of specific absorption of phytoplankton. Limnol. Oceanogr., 32 : 403-415.

SugawA, A. (1989) : Vertical attenuation coefficient of downward irradiance in Lake Oze. Jpn. J. Limnol., $50: 1-7$.

Weidemann, A. D. and T. T. Bannister (1986) : Absorption and scattering coefficients in Irondequoit Bay. Limnol. Oceanogr., 31 : 567-583.

(著者：須川 明, 群馬大学教育学部, $\uparrow 371$ 前橋市 荒牧町 4-2 ; 矢島久美子, 群馬県衛生公害研究所, 广 371 前橋市岩神町 3-21-19：Akira SuGAWA, Faculty of Education, Gunma University, Aramaki-cho 4-2, Maebashi 371 ; Kumiko Yajima, Gunma Institute of Public Health, Iwagami-cho 3-21-19, Maebashi 371)

Received : 25 February 1989

Accepted : 17 May 1989 